\title{
For-Profit Colleges in the Economic Crisis: Thriving in Tough Times?
}

\author{
Kai Yu (Corresponding author) \\ Graduate School of Education, Shanghai Jiao Tong University \\ Shanghai, 200240, People's Republic of China \\ E-mail: kyu@sjtu.edu.cn \\ Hubert Ertl \\ Department of Education, University of Oxford \\ Oxford, OX2 6PY, United Kingdom \\ E-mail: hubert.ertl@education.ox.ac.uk
}

Received: October 12, 2013 Accepted: November 26, 2013 Published: January 15, 2014

doi:10.5296/ire.v2i1.4414

URL: http://dx.doi.org/10.5296/ire.v2i1.4414

\begin{abstract}
Being closely connected to social, employment and financial factors, economic crises are expected to have influence on higher education. This study attempts to answer the following question: how has the economic crisis in 2008 affected for-profit colleges in the U.S.? To answer the question, this study samples from for-profit higher education companies that are listed on the U.S. stock market, and compares the companies' enrolment, financing and operations, and stock prices before and after the economic crisis took hold around July of 2008. This paper finds that, as for student enrolments, the scale of operation of the higher education companies has greatly increased in the crisis. Concerning finances and business operations, the companies significantly increased the revenues and profits in the crisis. Finally, the companies' stock prices greatly outperformed the market average in the crisis. The success of for-profit institutions in this economic crisis was determined by more than the economic consequences. While the economic climate mattered, the institutions themselves and the politics of regulation also played crucial roles.
\end{abstract}

Keywords: Economic crisis, financial crisis, higher education, for-profit universities; 


\section{Introduction}

In the summer of 2007, the financial crisis triggered by the surge of default cases in the United States subprime mortgage industry spread rapidly from the financial industry to the real economy, creating a great impact on the real economies of many countries. Being closely connected to social, employment and financial factors, economic crises are expected to have influence on higher education. This study attempts to answer the following question: how has the economic crisis affected for-profit colleges in the U.S.?

Companies providing higher education for profit have been a new and important phenomenon in the U.S. As these companies are starting to invest in the UK, Australia and other countries, for-profit higher education institutions are increasingly important in more countries. For-profit higher education companies not only operate differently from public and not for profit institutions, but their performance measures are different and they are not always included in standard statistical collections and analyses. The higher education market differs substantially from the general market (Ruch, 2001; Tierney \& Hentschke, 2007), and insight in the effects of the economic conditions on higher education can be relevant for economic theory and higher education institutions.

In the summer of 2007, the subprime mortgage crisis was an early indicator of the broader economic crisis that triggered panic and ultimately calamity in financial markets around the world. Along with exposing broader concerns in the financial markets, the crisis substantially hindered real economic activity in many countries. Looking at the financial reports of American Fortune 500 companies, profits in 2008 were $87 \%$ lower than those in 2006. This was the sharpest decrease in the list's 55-year history (Tully, 2009). The U.S. S\&P 500 Index peaked at 1,565 in October 2007 and fell to 683 in March of 2009, its lowest value in 13 years. This market loss was the greatest since the Great Depression in 1931 (Sommer, 2008).

After eight years of continuous growth, it was estimated that the global Gross Domestic Product, had, for the first time, decreased by $2.1 \%$, with medium- and high-income countries shrinking by 3.3\% (World Bank, 2010). The governments of many countries offered financial assistance to at-risk enterprises. Some countries were and have been in bankruptcy crisis. There is no doubt that this crisis has had substantial influence on the global economy. Being closely connected to social, employment and financial factors, what influence would the crisis have on higher education? The basic features of economic crises are decreases in the incomes and in employment rates of citizens (Fallon \& Lucas, 2002; Reinhart \& Rogoff, 2009). The reactions of individuals to these circumstances are of great interest to the higher education sector. It is possible that these circumstances will decrease the capacity of families to afford tuition fees. Similarly, some may voluntarily choose to postpone their schooling in favour of seeking employment in order to help support their families. Both would have a negative impact on demand for the higher education services provided by universities and colleges. On the other hand, some may see a difficult financial periods as a good time to invest in a higher education (Becker, 1990). Students may enrol to obtain valuable skills and knowledge before seeking employment and others may choose to pursue a higher degree while working in order to increase their job competency. Seeking higher education may also 
be used as a strategy for avoiding unemployment. These circumstances may lead to an increase in demand for higher education.

According to Windolf (1992), there are three contrasting theories on educational expansion that permit the formulation of hypotheses regarding the relationship between economic conditions and educational expansion. The 'human capital' theory predicts that universities expand apace with economic growth and technical progress, meeting the societal need for qualified personnel, thus higher education expands in times of economic growth and contracts in times of economic recession. The 'status competition' theory maintains that educational expansion continues, even accelerates, during economic recessions as people seek more credentials to improve their comparative advantage in obtaining employment. The third theory, the 'political' theory, stresses that higher education institutions' ability to expand is determined by the level of support from the government. The theoretical predictions of educational expansion in times of economic recessions and high unemployment can, based on the choice of basic assumptions, vary significantly.

Research evidence also points to different observations. Windolf (1992) explored the cyclical character of the expansion of higher education and the relationship between economic growth and the increasing enrolment rates in higher education in five countries from 1870 to 1985, and found that for most countries the data confirm the theory of 'status competition': universities expand particularly fast during times of an economic recession (e.g., Great Depression, 1890-1900; World Economic Crisis, 1929-1935). Frances (1990) also argued that higher education enrolment is counter-cyclical, tending to increase during recessions. Frances also lists a detailed group of factors that can be used to better predict the demand for higher education, including demand factors, revenue sources, education costs, ability to pay, student financial aid, and educational outcomes. But Froomkin (1990) assessed the impact of slowdown in economic growth for the period 1980 to 1984 and found that it caused higher education institutions experiencing difficulties in balancing their income and expenditures, and other functions of the university, such as construction, renovation of facilities, and maintenance also suffered, although most institutions managed to protect their instructional programs. Berger and Kostal's (2002) research also points out that tuition and average wage levels significantly affect enrolment demand, while state appropriations significantly affect enrolment supply. In this economic crisis, loan volume dropped sharply as the overall credit market tightened and the house prices dropped, and since savings and personal borrowing on the part of parents and students account for the largest share of higher education financing, the economic crisis presented extraordinary challenges for families with college-bound students (Bhaskar \& Gopalan, 2009).

Considering the non-profit higher education sector, economic difficulties have often resulted in a decrease in government support for higher education. Economic crises often result in both declines in national and local revenues and increased need for public funding as residents lose jobs, income, and health insurance. In the U.S., with tax revenue declining as a result of the this crisis (National Governors Association \& National Association of State Budget Officers, 2010), at least 43 states cut public higher education institutions and/or made large increases in tuition to make up for insufficient state funding (Johnson, Oliff, \& 
Williams, 2011). Class sizes were limited at some state higher education institutions, and a few institutions in the U.S. faced the risk of closure (Morey, 2004), and this is also true in many other developing and developed countries (Eggins \& West, 2010). For private universities, many also encountered difficulties due to the decrease in the value of their endowments and due to decreasing donations (Humphreys, Electris, Filosa, \& Grace, 2010).

But the problems faced by non-profit institutions were not faced by those in the for-profit sector. The for-profit institutions receive virtually no state support and donations, therefore are not affected by the decrease in these two sources of funding. This means for-profit higher education institutions may be affected differently by economic conditions. However, although unlike public institutions, for-profit institutions receive no direct state or federal subsidies, the federal government has provided much of their revenue through student grants and loans, students of for-profit institutions are eligible for governmental grants and loans if the institution meets certain criteria set by the government (Blumenstyk, 2011). For most for-profit institutions governmental grants and loans to students have actually constituted the majority or even nearly all of their revenue (Harkin, 2010a), therefore the ability of the government to meet the student grant and loan demands will have major consequence on for-profit institutions' revenue. Fortunately for the for-profit companies, these sources of support were not significantly influenced by the crisis. The role of this uninterrupted support is discussed in this research.

Since the 1990's, the number of for-profit universities and colleges, owned and run by private companies, has grown rapidly in the U.S. (Ruch, 2001). Many have been growing significantly and are now listed on the stock exchange. Together, these companies command more than two percent of the revenues flowing into higher education each year -- most of it originating from governmental student loans -- and about 10 percent of the nation's campuses (Ortmann, 2001), and account for $9 \%$ of the higher education enrolment in the U.S. (National Center for Education Statistics, 2011). For- and non-profit colleges differ from each other in both their operational methods and structures (Bailey, Badway, \& Gumport, 2001; Tierney \& Hentschke, 2007). Generally speaking, compared with non-profit universities and colleges, for-profit institutions seek to maximize profit, they operate as a business, provide education that is more immediately relevant to workforce and worker needs, offer educational services on a large scale, have higher proportions of part-time faculty, focus most of their attention on adult and other non-traditional students, many of whom might not be admitted to traditional public or non-profit institutions, and often focus on the development of distance learning and evening and weekend classes in shopping malls and storefronts (Altbach, 1999; Breneman, 2005; Kinser, 2007; Millora, 2010; Morey, 2004). It is also these characteristics that contributed to the success of the for-profit sector. Because of their business model, for-profit institutions largely provide education services in rented spaces or by way of distance education (Morey, 2004); this has offered advantage in allowing them to quickly expand their enrolments in accordance with demand. Therefore, for-profit institutions usually have more flexibility to expand, as such, if overall the higher education enrolment can benefit from the economic crisis, as the 'status competition' theory predicts, for-profit institutions may benefit more than the average. 
There is a lag of one or two years when trying to understand how national economic data corresponds with that of higher education. Many universities and colleges do not make their data public; therefore, it is relatively hard to obtain information that helps with understanding the impact of economic conditions on the financial stability of higher education institutions. The publicly listed higher education companies on the stock market provide a unique angle and make it possible to conduct timely research on the influence of the crisis on higher education. As listed companies, they are also required to abide by a series of rules, including those related to the timely disclosure of information. Not only should they issue annual reports, but must issue quarterly reports in addition. The availability of this data makes the study of recent circumstances possible. Also, the institutions' stock value, admission and additional operational data in addition to financial data can provide significant data for analysis. However, due to the inherent differences between non-profit and for-profit institutions, although for-profit education institutions can provide a unique and plausible angle for the analysis of the influences of the economic crisis upon higher education, the findings cannot be applied to non-profit higher education institutions directly.

\section{Methods}

The effects of the economic crisis spread fairly quickly. With the outbreak of subprime loan crisis in 2007 and financial crisis in 2008, effects on national economies and a wide range of industries were evident in 2008 and 2009 as loan volume diminished, property prices dropped, company profits declined, and unemployment rose. These effects should be felt at colleges and by students and parents fairly quickly as well. Students' ability to pay tuition and their demands for higher education should have been affected from 2008 and this is expected to directly affect the number of applicants to higher education. The number of enrolled students can also be affected as students may drop out because of financial difficulty. If the enrolment declines, revenue of higher education institutions is immediately affected, and the stock market will also react to the decline quickly - sometimes even before the decline actually happens as investors are keen to predict and avoid losses due to likely declines. Therefore, if the economic crisis can influence for-profit institutions, such influence should have been felt rapidly or even immediately after the crisis took hold. For this reason, 2008 is chosen as the mid-point, as this was the point when the financial crisis took hold and started to make clear impact on the economy and industries. This paper assesses the situation of the for-profit institutions after the point, and using situation before the point as a comparison.

Based on the data available, the paper chose a sample of four for-profit higher education companies that are listed on the U.S. stock market, and examines the variations in their student admissions, financing and operations as well as the changes in stock prices five years before and two years after 2008. These three aspects reflect the operation of such education companies under the pressure of challenging economic conditions. Stock prices not only reflex the operation of the companies, they also indicate the relative market expectations of the companies in the future.

Data for the aforementioned aspects are collected from these companies' filings to the U.S. Securities and Exchange Commission. These filings include the annual and quarterly reports, 
as well as from minutes of investors' calls. The stock prices are public data as well and are collected from Google Finance.

This study analyzes the data by comparing the variations of the three aspects before and after 2008, the operations of these companies conducted under significantly changed economic conditions are studied and an understanding of the judgments of the market toward higher education companies will be gained.

By 2011, there were a total of 28 companies listed on the U.S. stock exchange markets that classified as "schools" under the category of "service" by Google Finance. Among them are companies involved in non-higher education fields, such as K12 Inc., which offers primary and secondary education. Also included in this category are New Oriental and The Princeton Review, which mainly provide examination and supplementary education. This research will focus on companies in higher education. The 28 companies also include those based outside the U. S., such as New Oriental, ChinaEdu Corporation and Chinacast Education, etc. This research will focus only on U.S.-based higher education enterprises, in order to limit any variations in the impact of the economic crisis due to regional factors. In addition, there are also some newly listed companies, such as Grand Canyon and Bridgepoint, which were first listed at the end of 2008 or early in 2009 . They are also not included in this research given the lack of historical data. Four higher education enterprises are included in the present study, each of them is based in the U.S., and has been in operation for a sufficient length of time. All of the four companies offer educational programs and services both online and on-campus at the undergraduate and graduate levels, and they are the top 4 by their market values.

Table 1. Four sample higher education enterprises

\begin{tabular}{lll}
\hline Company & $\begin{array}{l}\text { Market Capitalization (as } \\
\text { of 4 March, 2010) }\end{array}$ & Main Higher Education Institution \\
\hline $\begin{array}{l}\text { Apollo Group, Inc. } \\
\text { (Apollo) }\end{array}$ & $\$ 6.34$ Billion & University of Phoenix \\
$\begin{array}{l}\text { DeVry Inc. } \\
\text { (DeVry) }\end{array}$ & $\$ 3.74$ Billion & DeVry University \\
$\begin{array}{l}\text { ITT Educational Services, Inc. } \\
\text { (ITT) }\end{array}$ & $\$ 2.21$ Billion & ITT Technical Institute \\
$\begin{array}{l}\text { Strayer Education, Inc. } \\
\text { (Strayer) }\end{array}$ & $\$ 1.83$ Billion & Strayer University \\
\hline
\end{tabular}

Throughout this study, the years stated are calendar years. For example, year 2007 refers to January to December 2007. For enrolment statistics, the number of students is recorded in the last month or last quarter of the year. For financial statistics such as revenue and profit, the numbers are recorded for the twelve months of the year. The only exception is Apollo, which uses a slightly different period for official reporting of operational results. For Apollo, the reporting period is December to November. For example, year 2007 for Apollo refers to December 2006 to November 2007 inclusive. Since the beginning and ending of a quarter for 
Apollo is different from the others, its data cover one month earlier than the data for the other enterprises. As this research mainly compares the business operations of the same company in different years, the fiscal reporting deviations among the enterprises will not be any major obstacle to this research. There were also some differences in the way of census. For example, DeVry calculates only "coursetakers" for graduate registrations, which refers to the number of courses taken by a student, thus, one student taking two courses is counted as two coursetakers. Since comparisons are made only for the same company at different periods of time, the differences in the way of census across companies will not be any major obstacle to the study.

\section{Results}

\subsection{Enrolment}

For for-profit higher education institutes, the number of students is one of the most important indicators, for it not only indicates the actual size of the institute, it also has decisive influence on the income and on its everyday operation. When research is done concerning the influences of the economic crisis on higher education institutes, the influence on the number of students is no doubt worthwhile to consider. The following figure presents the number of students of the four companies in the years 2003 to 2010 .

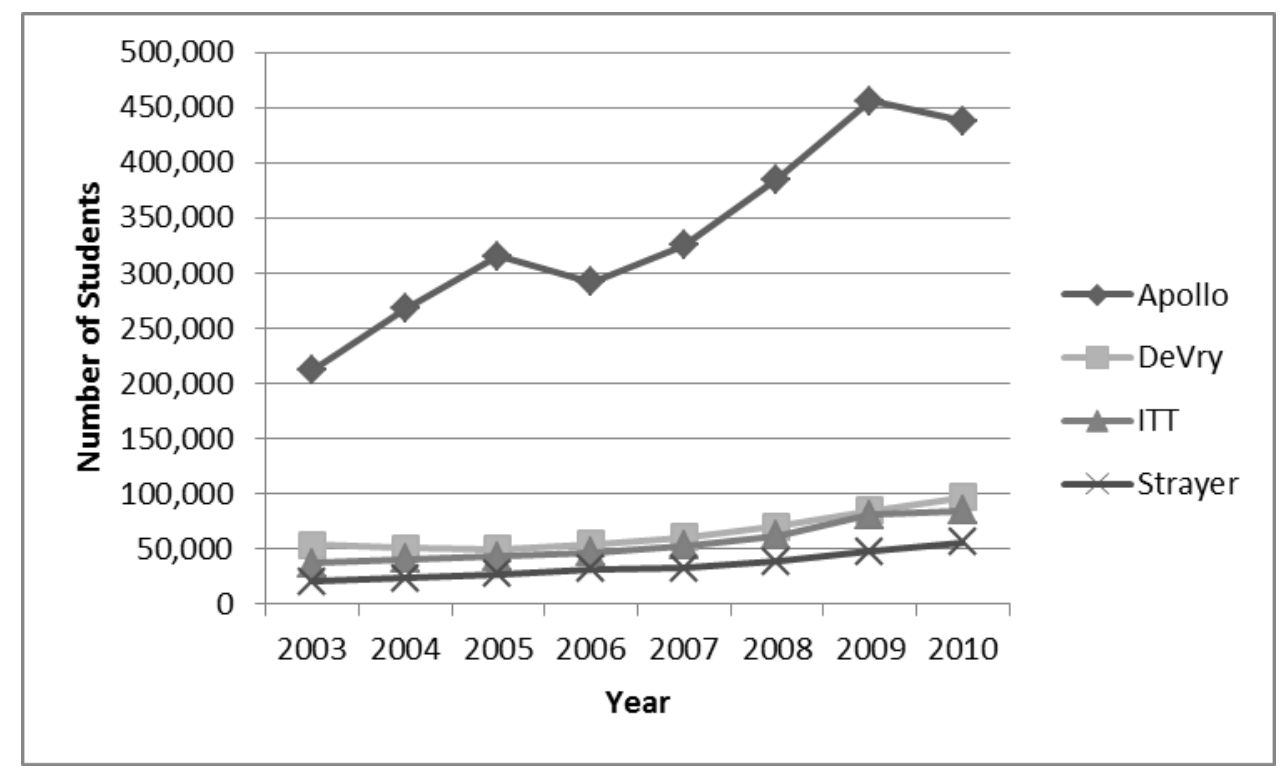

Figure 1. Enrolment of the four higher education companies

It is evident that the economic crisis had substantial influence on the financial system, and further on economic activity as a whole in the United States. But from the figure above, it is clear that the number of students at the for-profit institutions increased rapidly in the years 2007 to 2009. For the four companies, the growth of student enrolment in the four years from the end of 2003 to the end of 2007 was relatively steady, the student enrolment increased on average $42.3 \%$ (calculated as average of the four companies' growth rates), equivalent to a 
compound annual growth rate of $9.2 \%$. According to the National Center for Education Statistics, the total enrolment in degree-granting institutions, including public and private (for-profit and not-for-profit) institutions, increased $8 \%$ during the same period. However, since the beginning of 2008 , the growth had accelerated at the for-profit companies. In the two years from the beginning of 2008 to the end of 2009, the student enrolment of the four companies increased on average $45 \%$, equivalent to a compound annual growth rate of $20.4 \%$. Nationally, the total enrolment in all degree-granting institutions increased $12 \%$. This indicates that during the economic crisis, the number of students is not only on the increase but that it is increasing at a rate higher than that of the previous years.

The economy and financial system started to recover in 2010, and interestingly, and four companies' growth of enrolment had slowed down in the year. For the four companies, the average annual growth rate of enrolment in 2010 was only $8.4 \%$. The growth slowed down in all of the four companies and one company (Apollo) even saw a fall over the 2009 level. However, the decline of enrolment at this particular company was believed to be principally due to the change in the evaluation and compensation structure for their admissions personnel, the full implementation of University Orientation, and the changes in the company's marketing approaches (Apollo Group, 2010). These changes and initiatives may be triggered by the company's demands to meet the regulations, and are not a direct result of the economic crisis.

According to the companies' own analysis, the quick growth from 2007 to 2009 was primarily attributable to the economic uncertainties, as working learners seek to advance their education to improve their job security or reemployment prospects. The companies also forecasted that this element of growth may diminish as the economy and the employment outlook improve in the United States (Apollo Group, 2010; DeVry, 2010; ITT Education Services, 2010).

\subsection{Finance and Business Operation}

The total incomes and net profits before and after the beginning of 2008 are compared for the four companies in the following figures. The figures show that both total income and net profit increased significantly after the economy suffered. Revenue is the income the companies receive from their normal business activities, i.e. offering educational services to students, while Profit is the Revenue minus all expenses. 


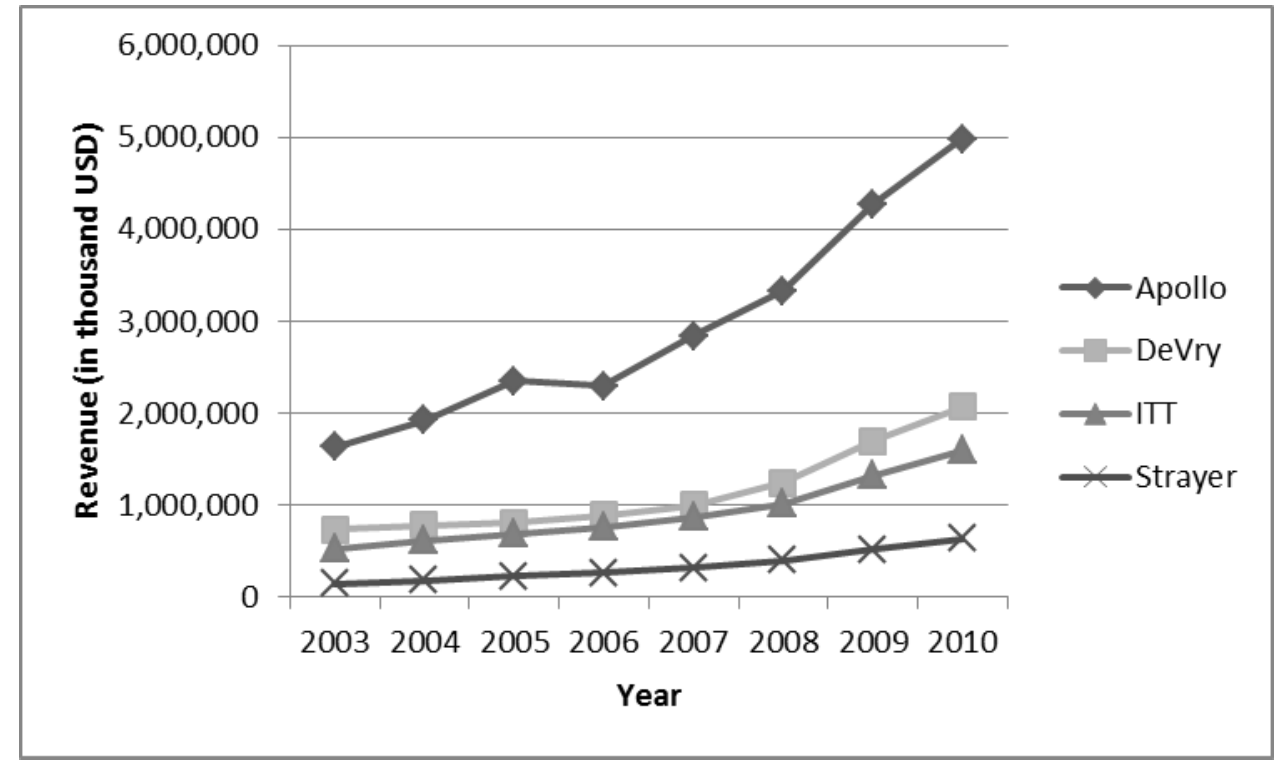

Figure 2. Revenue of the four higher education companies

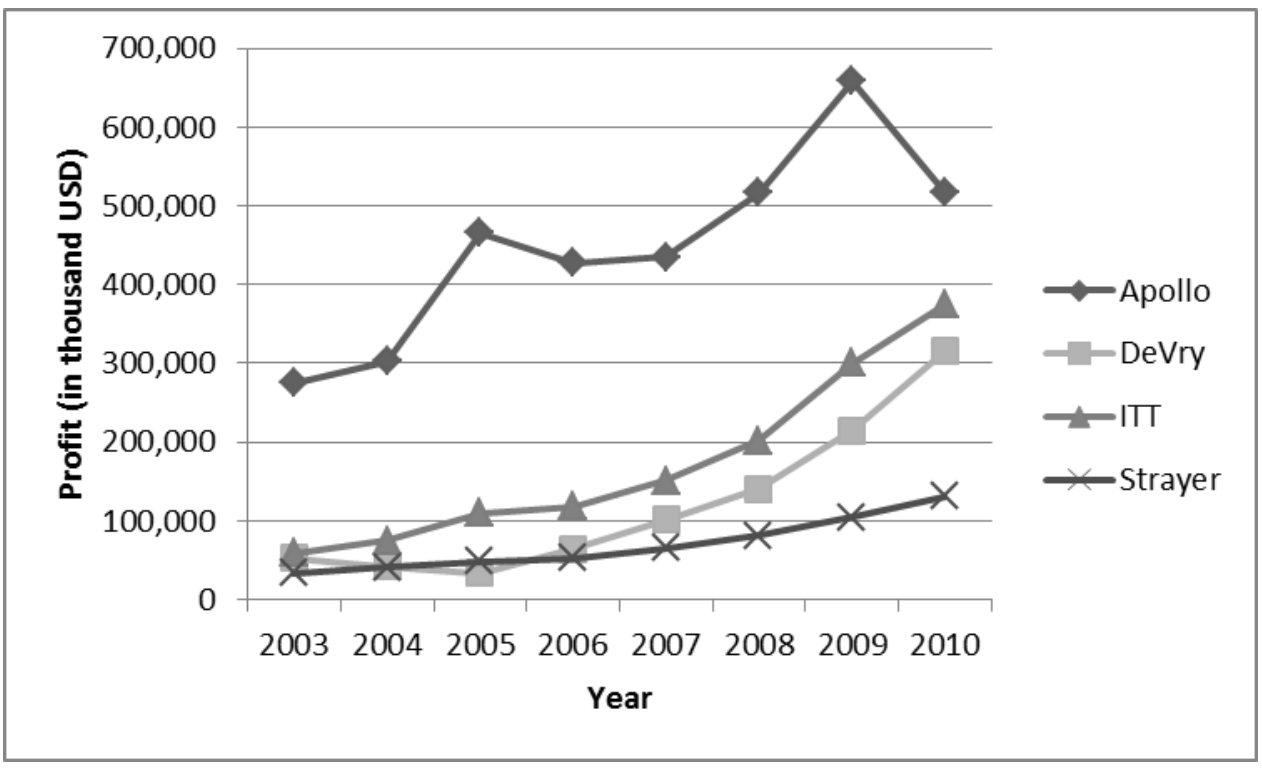

Figure 3. Profit of the four higher education companies

The income for for-profit higher education institutions largely comes from the tuition charges. Thus any increase in the enrolment means greater revenue and a likely profit increase. The figures show, that the total income and net profit of all four companies increased greatly along with enrolments during the economic crisis in 2007 to 2009. Also, the increase of total revenue and net profit is even higher that the increase rate of enrolment.

With regard to revenue, for the four companies, the growth of revenue in the four years from the end of 2003 to the end of 2007 was fast, the revenue on average increased $73.2 \%$ (calculated as average of the four companies' growth rates), equivalent to a compound annual growth rate of $14.7 \%$. However, since the beginning of 2008 , the growth had even 
accelerated. In the two years from the beginning of 2008 to the end of 2009 , the revenue of the four companies increased on average $58.1 \%$, equivalent to a compound annual growth rate of $25.7 \%$. In 2010, the growth of revenue continued at the four companies, but the speed of growth slowed down to a small extent. In 2010, the average revenue growth of the four companies was $21.1 \%$.

At the four companies, the profit increased at a faster pace than the revenue. As stated above, the growth of revenue in the four years from the end of 2003 to the end of 2007 was on average $73.2 \%$ (calculated as average of the four companies' growth rates), equivalent to a compound annual growth rate of $14.7 \%$, but in the four years the companies' average profits grew $100 \%$, equivalent to a compound annual growth rate of $18.9 \%$. Since the beginning of 2008 , the growth of profits had also accelerated. As stated above, in the two years from the beginning of 2008 to the end of 2009, the revenue of the four companies increased on average $58.1 \%$, equivalent to a compound annual growth rate of $25.7 \%$, but the profits increased on average $80.8 \%$, equivalent to a compound annual growth rate of $34.5 \%$. In 2010 , three of the four companies still saw profit growth, but at slightly declined speed (on average $32 \%$ ), and one company (Apollo) saw a fall of $21.4 \%$. The fall at Apollo was principally caused by the company's $\$ 184.6$ million impairment charge of its subsidiary companies in the year. If this charge was excluded the company's profit would have had increased $6.7 \%$ in 2010. Apollo's significant securities litigation loss of $\$ 97.2$ million, $\$ 160.2$ million, and $\$ 170$ million in 2008, 2009, and 2010 also contributed to the lower profit in these three years, if these were excluded, the profit growth in 2008 and 2009 over the previous year would have been even stronger.

The profits increased at a faster pace than the revenue because the expenses increased at a slower pace. For example, the higher education companies benefited from the economic crisis in advertising. The advertising market, like most industries, was hit by the economic crisis and the advertising rates had slipped significantly, especially in traditional, offline media. This had meant that the higher education companies could pursue different advertising strategies. Before the crisis, higher education companies often preferred online advertisements. However, because of the decrease in television and newspaper advertisement rates, educational companies could take advantage of these decreased rates (Apollo Group, 2009). Also with the decrease of real estate prices, the rental costs for classroom and administrative space also dropped sharply, which helped cut expenses and boost profits (Apollo Group, 2008).

Additional positive effects of the economic crisis on company operations include the decreasing appeal of other industries, especially the finance industry, that may gave higher education companies the opportunity to hire more highly qualified staff. Increased revenue also provided higher education companies with a larger cash flow, and thus with more opportunities for other investments.

However, the economic crisis also brought on some negative impacts on the finances of the institutions. These were mainly the decrease in student loans not guaranteed by the government and the increase in the incidence of bad loans. As the depth of the crisis was 
revealed, it was increasingly difficult for students to secure non-government backed loans. This fact made it more difficult for students to get loans overall (Bhaskar \& Gopalan, 2009). At the same time, there was a small increase in the tuition default rate. After the economy was hit by the crisis, there were a higher number of enrolments of undergraduate students entering with a low number of transfer credits. Collection rates for these students tend to be lower than students with more college experience and graduate degree students. While of concern, the significance of these two factors remains fairly small (DeVry, 2010). Again Apollo is used as an example, when compared with the same period the previous year, in the latter part of 2008, non-government-guaranteed student loans as a percentage of revenue decreased by $2 \%$, while the bad debt expense as a percentage of revenue increased by $0.3 \%$ (Apollo Group, 2008). The bad debt expense continued to grow as a percentage of revenue: by the end of November 2010, bad debt expense of Apollo as a percentage of revenue was $5.7 \%$ compared to $3.8 \%$ a year ago, as a result of the impact of the economic crisis (Apollo Group, 2010).

Overall, it appears that the economic crisis has had a net positive effect on the finances and business operations of for-profit higher education institutes. This helped them to greatly increase their revenue and profits.

\subsection{Stock Performance}

The economic crisis had a significant influence on the stock market. The panic of the investors was rampant, and there was generally, a sharp slide in the capital markets all over the world. Even those enterprises with strong operations could not maintain their value because the stock prices were determined by more than their historical financial status. The market expectation of the higher education companies, as well as of the industry as a whole, reflected the expectations of the market for their future profitability. Because the prices of individual stocks often fluctuate wildly over time, and because the stock market reacts quickly to economic conditions, in comparing the trend of stock prices of higher education companies and the overall market, we focus on the period from July 2006 to June 2010, that is, two years before and two years after July 2008 - the mid-point we chose. Setting stock prices in July 2006 as the starting point, the following figure compares the trends in the company stock prices and the value of the S\&P 500 Index from July 3, 2006 to June 30, 2010 . 


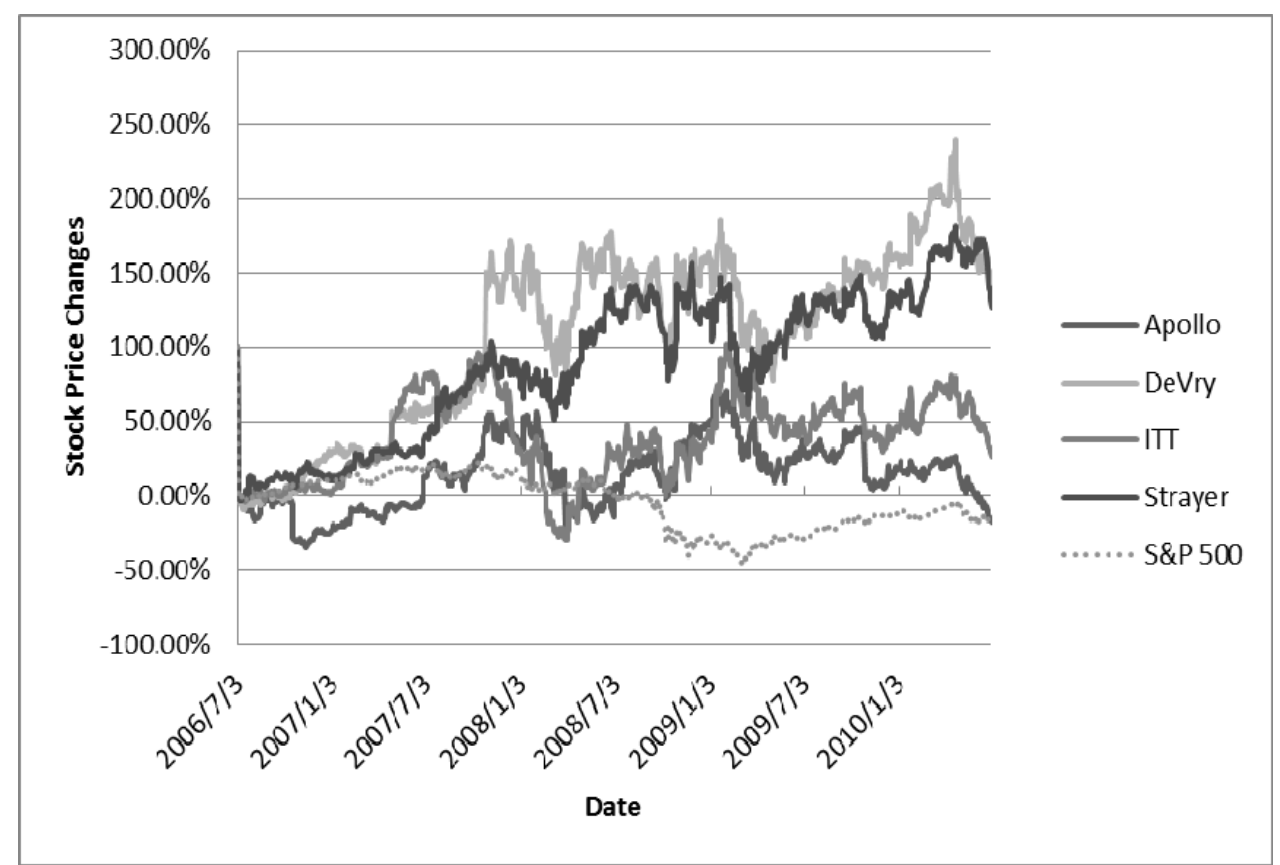

Figure 4. The Stock Prices of the Four Higher education Companies and S\&P 500 Index from July 3, 2006 to June 30, 2010

The figure shows that the S\&P 500 Index reached peak in October 2007 and began to fall, when it reached the 13-year low in March 2009 it had decreased 56\% since October 2007. This period shows the damage the economic crisis had on the stock prices of publicly listed companies. However, during the same period, the stock prices of the four higher education companies performed much better than the S\&P 500 Index. The stock prices of Apollo and DeVry increased $7.4 \%$ and $19.4 \%$, and stock prices of ITT and Strayer dropped merely $16.7 \%$ and $5.5 \%$, compared to a drop of $56 \%$ in the S\&P 500 Index.

Another phenomenon that can be seen in the figure is that, from the second half of 2007 to the beginning of 2008, the S\&P 500 Index dropped only slightly, whereas on average the stock prices of the four companies had dropped sharply. From June 2007 to March 2008, the ITT's stock price decreased by $60 \%$, while for the same period the S\&P 500 Index dropped by a mere $13 \%$. The sharp decrease in stock prices of the for-profit higher education companies in this period was mainly due to the instability of student loan market caused by the subprime loan crisis. This caused investors to worry about a potential decrease in the availability of student loans that would cause a decrease in company profits. However, after the U.S. Department of Education made it clear that it would provide liquidity for student loans the stock prices began to increase immediately (Smole, 2008). The stock prices continued to rise although the S\&P 500 Index dropped afterwards. These stock values demonstrate that investors believe that government policies on student loans will have significant impact on the operation and finance of higher education institutes. The ability of on-campus students to secure loans was essential to the economic prospects of the for-profit higher education industry. 
Beginning in March 2009, the U.S. stock market began to rise again. As shown in the above figure, up to June 19, 2009, S\&P 500 Index had gained over 25\% within 3 months. Yet educational enterprises showed an opposite trend. Despite a $22 \%$ rise in the stock price of Strayer, the other three companies had experienced a decrease in their stock prices. From March 2009 to March 2010, the S\&P 500 Index went up nearly 52\%, ahead of all the four for-profit higher education companies.

The period under study is of significant volatility for these stocks. Some of the volatility has been driven by specific litigation and investigations, and in general, the stocks reflect a great deal of investor concern about the sector's future prospects because of the uncertainty in the politics of regulation. Although it is demonstrated that the share pricing of for-profit higher education companies performed well in the crisis, the interaction between share pricing and the economic climate in is not clear.

\section{Discussion and Conclusions}

One of the major obstacles to research concerning the influence of the economic crisis on higher education is the lack of timely and accurate data. Methodologically, this paper uses descriptive and narrative information on enrolment, business operation and stock prices to investigate the situation of four publically listed for-profit higher education companies during the economic crisis. Although more sophisticated and reliable research methods can be used if data for longer periods can be obtained, this type of descriptive information yielded interesting results. The evidence shows that although the economic crisis has negatively affected both the global economy and many industries, the for-profit sector of higher education has not only survived the economic crisis but has thrived as enrolment and profit increased substantially and the stock prices outperforming market average.

The study demonstrated that enrolments, revenue and profits of for-profit institutions increased during the recession. The study has shown that, contrary to the economy and most other industries, the for-profit institutions thrived in the turbulent economic conditions. However, the study does not show whether that was caused by the recession or by other factors. One shall not draw the conclusion from this study that higher education or for-profit institutions can always benefit from economic crises, or that economic crises will always have positive effects on for-profit higher education. The results here in the study were caused by a combination of diverse and complex forces. The success of for-profit institutions in this economic crisis was determined by more than the economic consequences. While the economic climate mattered, the institutions themselves and the politics of regulation also played crucial roles. For example, the role of government was significant in the strong performance of higher education companies during the economic downturn. Over $70 \%$ of the revenue of the four companies came from the student scholarships and loans either provided or guaranteed by the U.S. government. If government loan and scholarship programs were to be cancelled or limited due to federal government financial difficulty or if there were a shift in the policy supporting for-profit institutions, the enrolment and finance of the these institutions would certainly suffer a heavy blow, which would to a great extent be reflected on the stock market, and the findings of this study would be completely different. 
Considering the current U.S. Congress's scrutiny of for-profit colleges (Harkin, 2010b; Kutz, 2010), such shift in policy seems not impossible.

\section{Acknowledgement}

This study was sponsored by the China National Education Sciences Planning Project NO. EFA110342.

\section{References}

Altbach, P. G. (1999). Patterns in higher education development. In P. G. Altbach, R. O. Berdahl \& P. J. Gumport (Eds.), American higher education in the twenty-first century: Social, political, and economic challenges. Baltimore, MD: The Johns Hopkins University Press.

Apollo Group. (2008). 10-K: Q4 2008. Phoenix: Apollo Group.

Apollo Group. (2009). Q2 2009 Earnings Conference Call. Phoenix: Apollo Group.

Apollo Group. (2010). 10-K: Q4 2010. Phoenix: Apollo Group.

Bailey, T., Badway, N., \& Gumport, P. J. (2001). For-Profit Higher Education and Community Colleges. Stanford, CA: Stanford University National Center for Postsecondary Improvement.

Becker, W. E. (1990). The Demand For Higher Education. Albany, NY, SUNY Press.

Berger, M. C., \& Kostal, T. (2002). Financial resources, regulation, and enrolment in US public higher education. Economics of Education Review, 21, 101-110. http://dx.doi.org/10.1016/S0272-7757(00)00065-0

Bhaskar, R., \& Gopalan, Y. (2009). As College Costs Rise, Student Loans Are Harder to Find. Inside the Vault, 13.

Blumenstyk, G. (2011). For-Profit Colleges Show Increasing Dependence on Federal Student Aid. The Chronicle of Higher Education, February 15.

Breneman, D. W. (2005). Entrepreneurship in higher education. New Directions for Higher Education, 129. http://dx.doi.org/10.1002/he.168

Devry. (2010). 10-K: Q4 2010. Downers Grove, IL: DeVry.

Eggins, H., \& West, P. (2010). The Global Impact of the Financial Crisis: Main Trends in Developed and Developing Countries. Higher Education in a World Changed Utterly: Doing More with Less. Paris.

Fallon, P. R., \& Lucas, R. E. B. (2002). The Impact of Financial Crises on Labor Markets, Household Incomes, and Poverty: A Review of Evidence. World Bank Research Observer, 17(P), 21-45. http://dx.doi.org/10.1093/wbro/17.1.21 
Fortune Magazine. (2007). FORTUNE 500 2007: FORTUNE annual ranking of America's largest corporations. Retrieved December 16, 2010, from http://money.cnn.com/magazines/fortune/fortune500/2007/index.html

Fortune Magazine. (2008). FORTUNE 500 2008: Annual ranking of America's largest corporations from Fortune Magazine. Retrieved December 16, 2010, from http://money.cnn.com/magazines/fortune/fortune500/2008/index.html

Frances, C. (1990). Key Economic Indicators for Higher Education. In K. H. Hanson \& J. W. Meyerson (Eds), Higher Education in a Changing Economy. New York: American Council on Higher Education and Macmillian.

Froomkin, J. (1990). Impact of Changing Financial Resources. Albany, NY, SUNY Press.

Harkin, T. (2010a). Emerging Risk?: An Overview of Growth, Spending, Student Debt and Unanswered Questions in For-Profit Higher Education. Washington, DC: US Senate Committee on Health, Education, Labor, \& Pensions.

Harkin, T. (2010b). The Return on the Federal Investment in For-Profit Education: Debt Without a Diploma. Washington, DC: US Senate Committee on Health, Education, Labor, \& Pensions.

Humpheys, J., Electris, C., Filosa, J., \& Grace, K. (2010). Educational Endowments and the Financial Crisis: Social Costs and Systemic Risks in the Shadow Banking System. Boston, MA: Center for Social Philanthropy, Tellus Institute.

ITT EDUCATION SERVICES. (2010). 10-K: Q4 2010. Carmel, IN: ITT Education Services.

Johnson, N., Oliff, P., \& Williams, E. (2011). An Update on State Budget Cuts: At Least 46 States Have Imposed Cuts That Hurt Vulnerable Residents and the Economy. Washington, DC: Center on Budget and Policy Priorities.

Kinser, K. (2007). Dimensions of corporate ownership in for-profit higher education. Review of Higher Education, 30, 217-245. http://dx.doi.org/10.1353/rhe.2007.0009

Kutz, G. D. (2010). FOR-PROFIT COLLEGES: Undercover Testing Finds Colleges Encouraged Fraud and Engaged in Deceptive and Questionable Marketing Practices. Washington, DC: United States Government Accountability Office.

Millora, M. L. (2010). Market Values in Higher Education: A Review of the For-Profit Sector. InterActions: UCLA Journal of Education and Information Studies, 6.

Morey, A. I. (2004). Globalization and the Emergence of For-Profit Higher Education. Higher Education, 48, 131-150. http://dx.doi.org/10.1023/B:HIGH.0000033768.76084.a0

National Center For Education Statistics. (2011). Digest of Education Statistics. Washington, DC: National Center for Education Statistics. 


\section{Macrothink}

International Research in Education

ISSN 2327-5499

2014, Vol. 2, No. 1

National Governors Association \& National Association of State Budget Officers. (2010). The Fiscal Survey of States, June 2010. Washington, DC: National Association of State Budget Officers.

Ortmann, A. (2001). Capital romance: Why Wall Street fell in love with higher education. Education Economics, 9, 293-311. http://dx.doi.org/10.1080/09645290110086153

Reinhart, C. M., \& Rogoff, K. S. (2009). The Aftermath of Financial Crises. NBER Working Paper Series.

Ruch, R. S. (2001). Higher Ed, Inc.: The Rise of the For-Profit University. Baltimore, MD: Johns Hopkins University Press.

Smole, D. P. (2008). The Ensuring Continued Access to Student Loans Act of 2008. Washington DC: Congressional Research Service.

Sommer, J. (2008). A Friday Rally Can't Save the Week. The New York Times, November 23.

Tierney, W. G., \& Hentschke, G. C. (2007). New players, different game: understanding the rise of for-profit colleges and universities. Baltimore, MD, The Johns Hopkins University Press

Tully, S. (2009). Pop! Went the Profit Bubble. Fortune Magazine.

Windolf, P. (1992). Cycles of Expansion in Higher Education 1870 - 1985: An International Comparison. Higher Education, 23. http://dx.doi.org/10.1007/BF00141141

World Bank. (2010). Global Economic Prospects Summer 2010. Washington, DC: World Bank. http://dx.doi.org/10.1596/978-0-8213-8226-4

\section{Copyright Disclaimer}

Copyright reserved by the authors.

This article is an open-access article distributed under the terms and conditions of the Creative Commons Attribution license (http://creativecommons.org/licenses/by/3.0/). 